\title{
Poland $^{1}$
}

\author{
Aleksandra Partyk
}

\section{Introduction}

The process of informatisation of the Polish administration of justice is far from being perfect. Polish judicature cannot be regarded as the most modern and effective system of the old continent. Judges and employees of the Polish administration of justice have become, however, equipped with certain - wider and wider - possibility to use modern technologies for professional purposes, although it seems that this possibility could be significantly broader. Undoubtedly, the absence of optimal utilisation of IT tools in the functioning of the administration of justice constitutes one of the causes - not as serious as understaffing and overburdening judges with work, though - that result in lengthiness of court proceedings ${ }^{2}$. For it is impossible to disagree with the claim that the final effectivity is influenced not only by procedures, but also by the work environment ${ }^{3}$.

In the current legal circumstances, it is out of the question for the administration of justice to be executed by artificial intelligence. It does not mean, however, that there is no possibility for the judges and court employees to use dedicated computer programs, including those utilising selected artificial intelligence mechanisms, which could have positive influence on the way the Polish administration of justice functions. Usefulness of these programs is beyond doubt. On the one hand they greatly contribute to improvements in the workings of courts (although undoubtedly there is still significant room for utilising modern technologies within the administration of justice in order to improve its effectiveness). On

1 The research was financed from the funds allocated for the maintenance and development of research potential in the discipline of legal sciences no. WPAiSM/ PRAWO/SUB/12/2021. Translated by Krystyna Sylwestrow.

2 Aleksandra Partyk, 'Initiating proceedings in a civil case using AI? Selected comments regarding Polish civil procedure' in: García G. Javier, Alzina L. Álvaro and Martín R. Gabriel (eds), El derecho público y privado ante las nuevas tecnologías (Dykinson 2020) 662.

3 Ł. Małecki-Tepicht, 'Rewolucja cyfrowa w sądownictwie - przegląd obszarów i narzędzi wzmacniania efektywności wymiaru sprawiedliwości’ (2020) 2 Iustitia 70. 
the other hand, informatisation of the administration of justice, even at its current stage, undoubtedly facilitates - and does so to a considerable extent - the accessibility of courts for the public, especially thanks to Court Information Portals which enable the parties, proxies and other authorised persons to access - by digital means - information on their court cases. In this study key IT solutions will be presented which are used on various fronts of the fight for an efficient legal process. As it will be demonstrated not all solutions which are currently in use entirely fulfil the tasks, they are assigned which demands the question to be asked about the need and possibility of modernising them.

\section{Electronic writ of payment procedure}

First of all, the so-called e-court (https://www.e-sad.gov.pl) is worth presenting. It is not an IT tool available to Polish courts at large. There is only one court which has been equipped with it so far, namely the District Court Lublin-West in Lublin, $6^{\text {th }}$ Civil Division which performs the function of a national court proceeding electronic writ of payment procedures ${ }^{4}$. The said district court is partialy competent to adjudicate cases under electronic writ of payment procedures regardless of the value of the asserted claim $^{5}$. Proceedings under this formula are subject to regulations included in the Code of Civil Procedure (CCP hereinafter) and were introduced in Poland on the 1st of January 2010. As it emphasized in literature court proceedings before the e-court are equivalent to proceedings taking place in an ordinary writ of payment procedure in which a court issues an order for payment, should it recognize a claim as well-grounded, while defendants may dispute the decision issued and have the right to submit a statement of opposition resulting in the order for payment becoming void's.

The legislator has unambiguously regulated what kind of claims can be considered under the electronic writ of payment procedure. Above all, this procedure is dedicated to prosecuting monetary claims only. It arises

4 Cf The regulation by Minister of Justice issued on the 14 December 2010, amending the regulation regarding determination of the district court to which adjudication is transferred of cases under the electronic writ of payment procedure, when other district courts are competent (Dz.U. 2010.245.1646).

5 Cf Katarzyna Jasińska, 'Czy "referendarza z Lublina" może zastapić "sędzia robot"?’ (2020) Studia Prawnicze. Rozprawy i Materiały 91.

6 ibid. 
from the procedural regulations directly that the issuance of an order for payment is excluded in cases where the plaintiff seeks to claim something else than money and when the order was to be served to the defendant out of the country. Only claims which became due during three years preceding the day the statement of claim is filed can be brought under this procedure. This corresponds to the general term of limitation considering claims for periodical payments and claims prosecuted by entities running economic activities (Cf. art. 118 of Polish Civil $\mathrm{Code}^{7}$ ). Prerequisites that prevent issuing an order for payment under the electronic writ of payment procedure are also as follows: an obvious lack of grounds for the claim and doubts regarding the facts on which the suit is based ${ }^{8}$. It is significant that no evidence is attached to the statement of claim filed under the electronic writ of payment procedure; the e-court takes a decision - to issue an order for payment or to discontinue proceedings due to the lack of grounds for issuing the order for payment - solely basing on the statements put by the claimant into the statement of grounds for the claim. This regulation, on the one hand, enables the claimant to obtain an order for payment relatively easily, it entails, however, the requirement of explaining all the circumstances important for the case precisely in the statement of grounds, as the court does not investigate any facts whatsoever beyond what the claimant offers. Whereas any doubts concerning the grounds for the brought claim lead to the refusal to issue an order for payment and termination of the lawsuit. What is more, the defendant can bring the legal existence of the order for payment to nullification by submitting a statement of opposition within two weeks counted from the day of service of the certified copy of the order ${ }^{9}$. The statement of opposition does not require any reasons, even a one-sentence defendant's letter from which it appears that they do not agree with the decision issued has legal effect. When a statement of opposition is submitted the court terminates the proceedings to the extent to which the order for payment which became null and void. Whereas an order for payment concerning which the defendant did not submit a statement of opposition within statutory period is effective equally to a valid judgment.

The electronic writ of payment procedure is not of obligatory character. And so the plaintiff can take advantage of the possibility for their case to

7 The Act of 23 April 1964, Civil Code (Dz.U. 2020.1740).

8 Cf Łukasz Goździaszek, 'Informatyzacja postępowania cywilnego' in: Kinga FlagaGieruszyńksa, Jacke Gołaczyński (eds), Prawo nowych technologii (Wolters Kluwer 2021) 153.

9 See the Supreme Court resolution of 9.06.2017, III CZP 21/17 (LEX no. 2301818). 
be adjudicated under this procedure (provided that certain prerequisites occur $)^{10}$ or they can file the case immediately under the "traditional” court procedure. What is more, the plaintiff has the possibility to initiate a "traditional" court proceeding later if the electronic writ of payment procedure ended when the decision to discontinue it was issued - whether because of the lack of grounds for issuing an order for payment or in connection with submission of a statement of opposition against the order for payment by the defendant ${ }^{11}$. Pursuant to art. 505(37) $\$ 2$ CCP if within the period of three months counted from the day the decision concerning discontinuation of the electronic writ of payment procedure was issued the plaintiff files the case against the defendant concerning the same claim but this time under a procedure other than the electronic writ of payment procedure, legal consequences which - pursuant to the relevant act - are connected with bringing legal action are effective as of the day of filing the case under the electronic writ of payment procedure. Should the parties demand that, the court - while adjudicating the case - will take into account the costs borne by the parties during the electronic writ of payment procedure.

The e-court is served by a dedicated IT system which operates the electronic writ of payment procedure. This system enables plaintiffs to file a case in electronic form, and if there is a need, submit documents complementary to the statement of claim. The plaintiff - pursuant to art. 505(31) $\$ 1 \mathrm{CCP}$ - can submit such a document solely using the teleinformatic system; and so there is no possibility for the plaintiff to submit any paper documents during the proceedings under the electronic writ of payment procedure. Therefore, in order to initiate legal action, the plaintiff has to possess an individual, secure account on the internet portal of the e-court. Filing a case results in creation of electronic case records ${ }^{12}$. Next, the case undergoes examination by e-court (a judge or a court clerk, Polish: referendarz sadowy) who decide if there are grounds for issuing an order for payment or for issuing a decision to discontinue the proceedings (if there are no

10 Katarzyna Franczak, 'Elektroniczne postępowanie upominawcze - zalety i wady dla stron postępowania' (2011) 7 PPH 48.

11 In previous legal environment filing the objection caused the order for payment to cease to have full effect and the case was transferred to a court of general jurisdiction. For example: the judgement of District Court in Oleśno of 4.03.2021, I C 962/19 (LEX no. 3153282).

12 Jasińska (n 5 ) 95. 
grounds for awarding the claim $)^{13}$. The order for payment, as well as any other decisions and orders are created in the form of electronic documents. Pursuant to art. 505(30) $\$ 2$ CCP actions of the court, the court official and the presiding judge are recorded solely in the teleinformatic system and qualified electronic signature is affixed to the electronic data created as a result of those actions ${ }^{14}$.

The legislator, however, stipulated two exceptions to the purely electronic form of the procedure discussed. Firstly, any judgements (an order for payment, a decision) and orders undergo serving in paper form, after their printouts are prepared. The delivery takes place via traditional post. Secondly, the defendant can submit their statement of opposition to the order for payment in paper form. The defendant may also, however, make a choice regarding submission of pleadings via the teleinformatic system, and in such a situation any following documents in the case are submitted by them via the system. According to art. 505(31) $\$ 3$ CCP documents submitted via the teleinformatic system do not require a handwritten signature.

It is emphasised in literature that the e-court cannot be reduced to the role of an administration of justice unit which runs electronic writ of payment procedures. For it is a qualified team of people who take care of the implementation of the rules of civil procedure ${ }^{15}$. Regardless of the in principle electronic form of the procedure discussed, this procedure is a sub-type of civil procedure and all the general rules of that procedure are applicable here. Therefore the electronic writ of payment procedure maintains all the basic procedural standards without which the right for a case to be adjudicated by an autonomous and unbiased court does not exist, in compliance with the fair play rule; still, because of the lack of running any evidentiary proceedings by this court, a number of recommendations proposed the judicature and within legal sciences, addressing the so-called procedural justice do not apply under this procedure at all.

13 Realizacja projektów informatycznych mających na celu usprawnienie wymiaru sprawiedliwości [Execution of IT Project Aimed at improvements in the administration of justice], Supreme Audit Office Department of Public Order \& Internal Security, evidence number: 160/2020/P/19/038/KPB.

14 Cf. Anna Brenk, 'Elektroniczne postępowanie upominawcze - kilka uwag na temat e-sądu', (2014) 3 KRS 10.

15 ibid 14. 
The IT system dedicated to the electronic writ of payment procedure is operated by people and is not in artificial intelligence systems' hands ${ }^{16}$. Not unreasonably, it is pointed out that the electronic system itself, dedicated for the electronic writ of payment procedure, is intuitive and relatively easy to operate. It is not flawless, however. For the system is not sufficiently adjusted to everyday reality's requirements, in particular, as of today, no application dedicated for mobile devices has been created. The system is also of autonomic character and is not sufficiently integrated with other services ${ }^{17}$. Breaks in its functioning happen, too, due to technical issues ${ }^{18}$. Periodically, in 2016 and 2017 the teleinformatic system was not adjusted to procedural regulations. This negligence resulted in a number of complications and forced judges and court officials working at that court to undertake several additional activities. The situation caused prolongation of e-court proceedings as well ${ }^{19}$.

Undoubtedly, for many entities the possibility to obtain an order for payment issued after completion of an electronic writ of payment procedure is a desired solution. The above stated is distinctively shown by the enormous number of cases filed under the electronic writ of payment procedure $^{20}$. For it is a procedure which - in Polish circumstances - enables an order for payment to be obtained remarkably fast. As it is demonstrated by the available data during the first half of 2019 the duration of a proceeding under the electronic writ of payment procedure amounted to (rounding off) 24 days, while in the year 2018 the figure was 26 days, whereas in 2017: 39 days respectively ${ }^{21}$. Unless a statement of opposition regarding the order for payment is submitted by the defendant, the order leads to the same effects as those connected with a legally valid judicial decision, in particular it can become an enforceable title subject to enforced debt collection, which undoubtedly constitutes an attractive alternative for the

16 Cf Jakub Pawliczak, Artur Pietryka, 'Elektroniczne postępowanie upominawcze ocena skutków regulacji', (2011) 4 KRS 31.

17 (n 13).

18 Information about such interuptions is presented on the website of e-court. For example: <https://www.e-sad.gov.pl/Aktualnosci.aspx?news_id=253 > accessed 22.05.2021.

19 (n 13).

20 In 2018 under electronic writ of payment procedure 1.419 .190 writs of payments were issued; in 2019 - 1.482.845 and in 2020 - 1.1516.277. Cf. 'Ewidencja spraw w zakresie elektronicznego postępowania upominawczego (EPU) w latach 2010-2020', <https://isws.ms.gov.pl/pl/baza-statystyczna/opracowania-wieloletnie> accessed 01.06.2021.

21 (n 13). 
'traditional' court proceedings, especially regarding class action (against banks, money lenders, or other entities rendering services to/for a broad array of consumer).

A doubt could be voiced, however, whether such mass issuance of orders for payments does not show in a sense that the administration of justice becomes fiction ${ }^{22}$. As it has already been discussed, a decision to issue an order for payment or to refuse to issue it is taken by a judge or a court clerk solely on the basis of the claims presented by the plaintiff, without verifying their genuineness using any evidence whatsoever, consequently - in a sense - automatically ${ }^{23}$. On the other hand, a statement of opposition, even if worded in general terms and lacking any grounds, results in an immediate annulment of the order for payment which was issued under the procedure. And so, the electronic writ of payment procedure is in a sense based exclusively on the statements presented by the parties involved in the procedure and the e-court does not undertake any evidentiary proceedings aimed at determining the actual state of affairs regarding the adjudicated case, consequently does not exercise the so-called objective truth rule.

Programs used for managing court proceedings and secretariat's work (Sawa, Sędzia-2)

The process of informatisation of Polish courts brought widespread replacement of court registers (repertories, lists, indexes) with electronic tools. For this purpose, programs Sawa and Sędzia-2 remain widely used by courts ${ }^{24}$. The primary function of these IT tools is maintaining a repertory/office system for court secretariats, they undergo, however, frequent modernisations and get equipped with new, additional functionalities ${ }^{25}$.

22 ibid.

23 Marek Załucki, 'LegalTech w sądownictwie' in: Dariusz Szostek (ed), LegalTech. Czyli jak bezpieczni korzystać $z$ narzędzi informatycznych $w$ organizacji, $w$ tym $w$ kancelarii oraz dziale prawnym (C.H. Beck 2021) 127.

$24 \mathrm{Cf}<\mathrm{https}$ ///lodz.so.gov.pl/container/wydzial-wizytacyjny/2016/sekretariaty/iii-rodz .-sr-pabianice.pdf > accessed 05.06.2021; <https://rzeszow.so.gov.pl/files/2a_spr.pdf $>$ accessed 05 June 2021.

25 Joanna Korolczuk, Informatyzacja postępowania sądowego. Szanse i zagrożenia, (2018) 4 Młody Jurysta 43 <https://www.google.com/url?sa=t\&rct=j\&q=\&esrc=s\& source=web\&cd=\&ved=2ahUKEwj5zez63oDxAhUymIsKHTbhC1QQFjACegQIA hAD\&url=https\%3A\%2F\%2Fczasopisma.uksw.edu.pl\%2Findex.php\%2Fmj\%2Far 
These programs comprise databases where basic information on every case adjudicated by a particular court division is (may be) posted. Each court proceeding is subject to registration according to a case reference number that has been assigned to it (including a designation of the court division, the repertory in which the case has been filed, the number of the case assigned to consecutive cases in the order they are filed and the year of registration). Personal information concerning the parties to the proceedings and other individuals taking part in the proceedings e.g. court experts or witnesses (names and surnames of natural persons, businesses and legal persons, as well as organizational units which are not legal persons) is entered into the system, as well as are their addresses. It is also possible to include some additional data regarding those entities, e.g. PESEL number, telephone numbers, e-mail addresses ${ }^{26}$. All significant actions connected with a particular judicial proceeding are subject to registration in the system, beginning with the fact and date of filing the suit or a motion which initiates proceedings, following with further procedural acts right up to the legally valid completion of the proceedings and sometimes even after it finishes (e.g. issuance of an enforceable title). Concerning documents submitted by the parties to the proceedings or other persons, only a note is posted in the system - indicating what type of document it was - from which one can learn just who and when submitted the document. Whereas all the documents originated in court (decisions, minutes of sessions, official written records) are entered into the system in their entirety (an electronic document whose content is identical to the paper document, e.g. a judicial decision, which is in the files of the case) is put into the system. That enables a quick determination of the course of a particular judicial proceeding even if there is no possibility to physically access the files of the case; moreover, it facilitates the process of creation of certified copies of court-originated documents. It is also noted down in the system where the case files are currently located, which is exceptionally useful in everyday court functioning practice ${ }^{27}$.

The possibility to search through information stored by those programs according to various criteria is their key function. Obtaining detailed information on a particular court proceeding can take place not only after the case reference number is entered into the search window, but also in a

ticle\%2Fdownload\%2F2990\%2F2727\%2F\&usg=AOvVaw3p7bnSlpZXcKkGpdY9 x91 $\mathrm{m}>$ accessed 05 June 2021.

26 ibid.

27 Cf $<$ https://nawokandzie.ms.gov.pl/numer-13/wokanda-13/akta-pod-kontrola.htm l> accessed 05 June 2021. 
different way. In particular, it is possible to determine whether any court proceedings are underway which involve a certain person. It is not out of the question that the desired information is unearthed basing on the date of a hearing, or even in the course of searching through all proceedings conducted by a particular judge ${ }^{28}$.

The abundance of information disclosed by these programs makes them effective tools in the course of preparing various statistics regarding operations of courts. In particular, it is possible to establish - in a fully automated manner - how many active lawsuits is a certain judge conducting at a given moment, how many cases were filed in their department during a certain period, how many cases the judge has closed or how many statements of reasons they prepared. Functionalities connected with statistics enable also to establish, for example, the number of court cases which within a given period of time ended with a judgement awarding the complaint or petition, a decision to dismiss it, discontinuation of the lawsuit or a settlement.

A function which is very important from the perspective of care for a correct course of court proceedings is the integration of repertory-office programs with the system of electronic confirmation of correspondence reception which is run by Poczta Polska [the Polish national state-owned mail company] which has been appointed the operator performing the delivery of court letters. An electronic confirmation of reception consists in delivery of a letter or parcel basing on a record present on a teleinformatic system and subsequently setting down a signature by the recipient on a mobile device ${ }^{29}$. Thanks to linking the electronic confirmation of reception with the repertory-office programs immediately after correspondence is delivered to a recipient, appropriate information appears in the court's system. Electronic confirmations of reception of correspondence sent regarding every court case undergo printing out and putting into the case's records. The functionalities presented are therefore of great importance from the practical point of view, more so, however, for the court administrative staff than members of judiciary. From the judges' perspective usefulness of the discussed tools is sometimes evaluated point-blank critically ${ }^{30}$. It stems from the very essence of these programs which - being

28 ibid.

$29 \mathrm{Cf}<\mathrm{https}: / /$ www.poczta-polska.pl/biznes/korespondencja/elektroniczne-potwierdz enie-odbioru $>$ accessed 01 June 2021.

30 Cf 'Currenda, czyli program "nowocześnie utrudniający życie sędziom', <http://w ww.pozywam.pl/2015/08/currenda-czyli-program-nowoczesnie.html $>$ accessed 29 May 2021. 
repertory and office connected - are dedicated for court secretariats, not for judges. Nevertheless, it is impossible to avoid coming to conclusion that from the perspective of efficient handling court proceedings and managing the work of court secretariats utilizing IT tools of such kind (obviously, allowing for the purposefulness of their modernization and up-dating) is necessary and constitutes a real improvement, uncomparable to the previous solutions based on paper repertories, lists and indexes.

\section{Software used for recording court sessions}

Pursuant to art. $157 \$ 1 \mathrm{CCP}$ an open session results minutes prepared by a court reporter. Minutes are prepared using a device that records sound or sound and video as well as in writing as instructed the presiding judge. Currently it is common to record the course of open sessions (particularly hearings) using sound and video recording devices. Most courtrooms have been equipped with video cameras and microphones that enable that task to be completed.

Operation of the process of recording court session is conducted using dedicated software. One of such programs is ReCourt which has been adjusted to the specific character of recording court sessions. This software combines functions of sound and video recorder with word processor which enables drawing up written minutes. The written record is in such a situation edited in the form of 'notes' synchronized in time with the sound and video recording ${ }^{31}$. The written minutes are also subject to copying and pasting into the repertory-office system functioning at a given court (Sawa, Sędzia-2).

The sound and video recording, along with the written notes is saved, and after that it can be played without any limitations. On application from the parties to the proceedings a CD/DVD containing the recording can be given to them. It is also possible to familiarize oneself with it via the Information Portal (Portal Informacyjny) ${ }^{32}$.

31 Cf $<$ https://www.rzeszow.so.gov.pl/files/instrukcja_v.3.0.pdf $>$ accessed 05 June 2021.

32 For more about the recordings of court sessions see: <https://www.arch.ms.gov.pl/ $\mathrm{pl} /$ sady-w-internecie/e-protokol> access: 01 June 2021. 
Covid-19 epidemics influenced numerous changes in law, which was postulated in literature ${ }^{33}$. In particular, that challenging time brought about acceleration of the pace of work on conducting sessions by Polish courts in a remote mode. Pursuant to art. 15zzs(1) clause 1 of the Act of 2 March 2020 on exceptional solutions connected with preventing, counteracting and fighting COVID-19, other contageous diseases and crisis situations caused by them ${ }^{34}$ during the period when the state of epidemiological threat or the state of epidemic announced due to COVID-19 and for a year after the latter was called off, in cases heard under the Code of Civil Procedure regulations, hearings or open sessions are conducted using technical devices which enable conducting them remotely, directly transmitting the sound and video simultaneously over the distance, provided that the persons taking part do not need to be present in the building where court is located, unless conducting the hearing or the open session without the use of the above mentioned devices will not cause excessive risk for the health of individuals taking part in proceedings.

The introduction of software operating remote sessions into Polish courts involved the necessity to couple the functions indispensible for conducting teleconferences with the option to record the course of the session using the already existing software (ReCourt). As a result of the above mentioned, recording a hearing conducted in the remote mode involves recording video and sound from the courtroom and from the program operating the teleconference.

The videoconference system is based on the Videoconference Platform which utilizes Avaya-Scopia or Jitsi software and is made available by the Court of Appeal in Wrocław. The court before which a certain proceeding is taking place becomes the organiser of the session or hearing conducted in the videoconference mode and moderates its course. The organizer of the videoconference manages its course and decides about participation of Attendees. The session moderator (a judge) can switch off all the attendees' microphones and give floor solely to chosen persons $s^{35}$.

33 Cf Aleksandra Partyk, 'Epidemia (COVID-19) a tok postępowań cywilnych i sądowoadministracyjnych' (2020) 5 PPP 42.

34 Dz. U. 2020.1842.

$35 \mathrm{Cf}<$ https://wroclaw.sa.gov.pl/container/Wideokonferencje/Regulamin\%20System u\%20Wideokonferencji \%20(003)\%20-\%20Kopia.pdf> accessed 01 June 2021 and $<$ https://wroclaw.sa.gov.pl/container/Wideokonferencje /Zestaw\%20dobrych\%20praktyk_v2-0.pdf > accessed 01 June 2021. 
Organising videoconferences using Avaya-Scopia software takes place via a portal accesible at the internet address: https://cpw.wroclaw.sa.gov.pl . The essential condition for organisation of a videoconference based on the Avaya-Scopia software is establishment of an account ${ }^{36}$. Whereas if Jitsi software is used, the court sends e-mail messages to the parties, their proxies or other persons. The messages contain a link which enables joining the remote hearing. Downloading or installing any software is not required ahead of the hearing. It is also possible to take part in a remote hearing using a smartphone via the Jitsi Meet application ${ }^{37}$.

\section{Information Portals}

From the perspective of the parties to the proceedings, and especially from the point of view of legal professionals representing them, Common Courts' Information Portals are exceptionally useful tools. For they constitute tools which enable entitled or authorized entities to access information on a lawsuit taking place with their involvement. Information Portals are linked with repertory-office systems used at a particular court, as well as with software used for recording hearings ${ }^{38}$. By way of example, persons who decide to use the Portal do not need to contact the secretariat employees in order to find desired information ${ }^{39}$.

In order to use the Information Portal one is required to set up a free-of-charge personal account. Thanks to such an account the registered users gain access to plentiful information regarding, among others, the state of their court case (which means the stage a certain proceeding is at), actions undertaken in the course of the case (with annotations pointing to dates and persons performing them), dates of sessions and hearings. The

$36 \mathrm{Cf}<$ https://wroclaw.sa.gov.pl/container/Wideokonferencje/Instrukcja\%20instalo wania\%20Scopia\%20-020przegl\%C4\%85darki\%20\%2B\%20mobile\%20v1-4.pdf accessed 01 June 2021.

$37 \mathrm{Cf}<$ https://wroclaw.sa.gov.pl/container/Wideokonferencje/instrukcja\%20po\%C5 \%82\%C4\%85czenia\% 20JITSI\%20-020dla\%20obywatela\%20v1-3.pdf $>$ accessed 01 June 2021.

$38 \mathrm{Cf}<$ https://czestochowa.so.gov.pl/portal-informacyjny,new,m1,190,231.html,1370 $>$ accessed 01 June 2021.

39 Cf Ewelina Mikołajczuk, Analiza funkcjonowania Portali Informacyjnych Sadów Powszechnych, Instytut Wymiaru Sprawiedliwości, Warszawa 2020, 16. <https://iw s.gov.pl/wp-content/uploads/2021/02/IWS_Miko\%C5\%82ajczuk-E._Analiza-fun kcjonowania-Portali-Informacyjnych-S\%C4\%85d\%C3\%B3w-Powszechnych.pdf accessed 1 June 2021. 
Information Portal makes it also possible to familiarize oneself with documents generated by the court while adjudicating the case which are subject to being entered into the repository-office system (e.g. decisions and their grounds, session minutes). One significant function of the Information Portal is access to electronic minutes. If the session underwent recording using voice and video capturing devices the audio recording form that session is subject to being made available via the Information Portal ${ }^{40}$.

Information Portals have become working tools exceptionally willingly used by persons who take part in court proceedings. In the period between the $1^{\text {st }}$ of December 2019 and $30^{\text {th }}$ of November 2020 Information Portals have been logged on to over 23 million times, over 21 million documents and nearly 0.5 million minutes were downloaded from them or read. Around $70 \%$ of Polish legal practitioners, who took part in the research conducted, use Information Portals daily, while further $26 \%$ do so a few times a week. Almost $95 \%$ respondents expressed generally positive opinions as for their functioning ${ }^{41}$.

\section{PESEL-SAD}

From the perspective of informatisation of courts another system is significantly important as well, namely PESEL-SAD which is an exact copy of the PESEL base, only created for the purpose of being used during court proceedings ${ }^{42}$. The PESEL number (Powszechny Elektroniczny System Ewidencji Ludności, English: Universal Electronic System for Registration of the Population) is assigned to every Polish citizen (and to foreigners, in certain situations $)^{43}$ and - thanks to its unique character - enables individualisation of every person to whom it was assigned ${ }^{44}$. Selected employees of

40 (n 38).

41 Cf Mikołajczuk (n 39).

42 Cf The Province Administrative Court in Warsaw judgment of 26.10.2015, II SA/Wa 1135/15, LEX no. 1940909.

43 Data gathered in the register concerns people who reside in Polish Republic on a permanent basis, have a permanent residence or temporary residence (over 3 months) registration, as well as individuals who have applied for an ID card or passport. It also contains information regarding individuals for whom there are grounds for possessing the PESEL number pursuant to separate regulations. $C f$. https://www.arch.ms.gov.pl/pl/sady-w-internecie/peselsad/ (access: 17.05.2021).

44 Pursuant to regulations of the Act of 24.09.2010 on population registration (Dz.U.2021.51) changing the PESEL number is acceptable only in exceptional situations, among others, following sex change. 
common courts, judges and court secretaries in particular, are authorised to use the PESEL-SAD database ${ }^{45}$. The documentation concerning the PESEL-SAD system is subject to protection. As The Province Administrative Court in Warsaw stated in the jugdgment of $26^{\text {th }}$ October 2015 in the case II SA/Wa 1135/15 ${ }^{46}$ the Polityka Bezpieczeństwa Systemu Informatycznego PESEL-SAD (PESEL-SAD IT System Security Policy) constitutes classified information and disclosing it to unauthorised persons could negatively impact executing tasks within the realm of public safety and administration of justice, or even lead to threatening the rights and freedoms of the citizens.

Access to the PESEL-SAD database results in streamlining proceeding in court cases primarily because it enables unequivocal identification of the parties to a particular proceeding, therefore eliminating the risk arising from concurrence of names and surnames. On the other hand, linking a PESEL number with a particular individual (e.g. the defendant) makes it possible for a judge to verify whether the lawsuit is conducted in fact against the person indicated in the stated of claim as being sued ${ }^{47}$. It is worth pointing out that the plaintiff, while initiating a legal action, is obliged to indicate their own PESEL number in the statement of claim and at the same time they should include information which enables identification of the defendant ${ }^{48}$. Pursuant to art. 208(1) in principio CCP the court ex officio determines the PESEL number of a defendant who is a natural person. The Regional Court in Bydgoszcz in its decision of $14^{\text {th }}$ of March 2014 in the case II Cz 73/14 (LEX no. 1661570), emphasised that the act described in art. 208(1) CCP, should be performed by the presiding judge in the court hearing the case, using the PESEL-SAD database which was created for this purpose and only upon establishing that data provided in the statement of claim are insufficient for the purpose of determining the PESEL number should they order the plaintiff to supplement the missing information under the threat of suspending the action pursuant to art. $177 \$ 1$ clause 6 CCP. Determining the number which identifies the defen-

45 Probation officers are also authorised to access the database.

46 LEX no. 1940909.

47 Cf The judgment of District Court in Gdynia of 4.07.2019, I1 C 3473/2018 (LEX no. 2748032).

48 It could be pointed out that within the electronic writ of payment procedure the plaintiff is obligated to indicate the defendant's PESEL number as well, what remains, however, a kind of peculiarity comparing to cases heard under other procedures. See also: https://www.e-sad.gov.pl/Subpage.aspx?page_id=42(access: 17.05.2021). 
dant is at most times uncomplicated once the court has a set of data (name, surname, address, and sometimes the date of birth $)^{49}$.

Access to the PESEL-SAD database is of great importance also due to the fact that the discussed database contains address information. Regarding selected court cases adjudicated under non-contentious procedures (e.g. concerning establishment of easement, acquisitive prescription, or inheritance) the court ex officio determines the circle of persons interested in the case and summons them to take part in the proceedings. The possibility to establish those persons' address information on the spot, by means of the PESAL-SAD system, significantly streamlines and accelerates the proceedings.

Moreover, information regarding civil status of individuals, including their deaths, is entered into the PESEL-SAD database and regularly up-dated. Whereas the death of a party to proceedings constitutes an obligatory prerequisite for suspension of a civil proceeding (art. $174 \mathbb{1} 1$ clause 1 $\mathrm{CCP}$ ), whereas conducting proceedings involving a deceased person constitutes grounds for invalidity of those proceedings (art. 379 clause 2 CCP). And so the possibility to verify whether parties to a proceeding are alive is exceptionally useful from the perspective of ensuring the proper course of proceedings. Unfortunately, until today repository-office systems used by courts have not been integrated with the PESEL-SAD database, therefore the function of automatic verification of whether the parties to a proceeding remain alive does not exist. Introduction of such a solution in future is worth postulating.

\section{System of Random Allocation of Cases}

In the current legal environment allocation of cases to judges for adjudication is done by means of an IT tool, named: 'System Losowego Przydziału Spraw (SLPS)' [System of random allocation of cases]. The system is supposed to evenly distribute cases to be heard by particular judges adjudicating in a certain court. Nevertheless, not every court case is equally complex and requires identical amount of time and work in order to be adjudicated. Allocating the same number of cases to judges itself would not mean that they are equally burdened with work. As it is pointed out in literature

49 Aaleksandra Partyk and Tomasz Partyk, 'Niewskazanie numeru PESEL jako brak formalny pozwu. Glosa do postanowienia s. apel. z dnia 11 marca 2015 r., I ACz 244/15' (2015) LEX/el. 
"creating a system which exercises the rule of even load fully and in an extreme and inflexible manner must take place at the expense of infringing equal chances of parties for their cases to be adjudicated within reasonable timeframe" ${ }^{50}$. Since one could envision a situation when two judges receive the allocation of identical number of cases, yet those allocated to the first judge are really simple, whereas the ones allocated to the other judge are complicated and multi-thread. The SLPS system is supposed to solve this problem thanks to classifying cases into certain categories before the random draw.

The Ministry of Justice points out that the report generated by the system upon the draw is a result of a greatly complex process influenced by a number of various factors which are usually known only at the court conducting the draw ${ }^{51}$. Such a report contains the case reference number, the date of the draw, the number of the draw, category and symbol of the case, the cost of the case, the result of the draw, indication of the judge to whom the case was assigned, as well as the number of judges who took part in the draw. Additionally, the load of cases existing before the draw is indicated, along with the figure randomly assigned to the case. Consequently, the report allows one to determine that the draw did take place and which one of the judges working in a certain court is to adjudicate in the assigned case, basing on several variables ${ }^{52}$.

Allocation of cases should be transparent, in order to eliminate any abuse. What still remains problematic is the fact that it has not been revealed to the public and to judges at large, exactly how SLPS functions and precisely what algorithm the draw is based on. It is noted in literature, and rightly so, that the lack of openness in this matter might infringe the right for a case to be adjudicated by an independent and unbiased court, since it is not known how the cases are allocated to particular adjudicator ${ }^{53}$. The outright fear arises of an instrumental use of the tool in order to influence the makeup of a particular judging panel. Although an assumption should be made that every judge to whom a case is allocated for adjudication will conduct it in a way compliant with the code of conduct in order for the judgement issued to be fair and to take substantive and procedural

50 Paweł Rygiel, 'Losowy przydział spraw cywilnych w sądzie drugiej instancji' (2019) 2 PS 49.

51 The Province Administrative Court in Warsaw judgment of 12.11.2020, II SAB/Wa 352/20, LEX no. 3106939.

52 The Province Administrative Court in Warsaw judgment of 12.11.2020, II SAB/Wa 352/20, LEX no 3106939.

53 Rygiel (n 50) 50. 
regulations into account, it does not seem to be an argument, however, which sufficiently justifies acknowledging that the failure to reveal the mechanism of SLPS's functioning does not remain a problem ${ }^{54}$.

\section{Summary}

In the last decade the Polish justice system has undergone a revolution which was connected with the computerisation and informatisation, whereas the work in the field has not been finished yet. The existing solutions need to be assessed in principle positively. However, they are not sufficient to meet the actual needs, in particular when assessed from the view of the problem of the lengthiness of court proceedings. One can say that the solutions based on modern technologies have been introduced in Polish civil cases across some spots, but not in a global way. Surely the already existing mechanisms significantly support the performance of the justice system. The exploitation of information technology advancements makes access to courts much more convenient for parties and their proxies. Electronic Procedure by Writ of Payment is of autonomous character, however on the national scale it is a huge relief for the courts of their workload with regard to cases connected with payments (particularly for a small value of the matter in issue). Still, a coherent, complex solution aimed at full informatisation of court cases, for instance by digitalisation of court records, is missing. An overhaul which will usher the Polish justice system into the XXI century needs to be deemed desired. This undoubtedly requires a broad discussion from both legal and technological perspective, and what is more, an analysis of regulations implemented in other countries, along with their effectiveness, so that the modernisation of Polish courts could lie up to the expectations aroused by it.

54 It is worth mentioning that the stance has been expressed in the body of penal judicial decisions according to which infringement of the rules concerning allocation of cases based on a system does not as such automatically mean that unconditional grounds for appeal exist regarding particular proceedings; it does not exclude, nevertheless, examination whether such a circumstance does not result in a violation of procedural provision if it could have influenced the content of the judgment. The Supreme Court decision of 17.07.2019, V KK 296/19, LEX no. 2696866. 
